\title{
Deconstructing Sport: When Philosophy and Education Meet in Derrida's Thought
}

\author{
Emanuele Isidori
}

University of Rome “Foro Italico", Italy

ABSTRACT

\begin{abstract}
Jacques Derrida (1930-2004), master of the deconstructionist method and recognized as one of the greatest thinkers of our time, was in his youth, before beginning his career as a philosopher, a footballer who played this game with the Italian prisoners in Algiers, his birthplace, during World War II. In a 1991 interview, when he was 60, Derrida narrated in detail his childhood dream of becoming a professional football player, confiding that all of his philosophy and thought had been inspired by sport and the game of football. Starting from this biographical note, the aim of my study is to demonstrate, first of all, how Derrida's whole philosophy and technique of deconstruction really has its roots in the concept of sport. The FrenchAlgerian philosopher understood sport as a cultural structure based on the concepts of play, game, body, rules, and all of the oppositional pairs deriving from différance and from the tensions it generates. Secondly, the study tries to show how sport is for Derrida a metaphor of life and its meaning, suspended between being and nothingness; a place and a field in which human beings act, learn and educate themselves, deconstructing, as in a text, the values and prejudices of their lives and understanding, through sport itself, their roles and responsibility toward themselves and the community in which they live.

sport, deconstruction, education, Derrida, philosophy
\end{abstract}

KEYWORDS

\section{Sport as a metaphor of philosophy}

In a 1991 interview, when he was 60, Derrida narrated in detail his childhood dream of becoming a professional football player. He confided that all of his philosophy and thought had been inspired by sport and the game of football (Hutchinson 2005). During this interview in which he talked about his experience as a football player, Derrida said that: «Beyond the touchline there is nothing» (Bennington 1999).

The starting point of this study is to ask, what is the exact meaning of this nihilistic sentence which seems inspired by Husserl, Sartre, Heidegger, Nietzsche? Maybe it is that for a football player the only important thing is to play, to live his emotions freely and not to mind what happens off the football pitch (beyond the touchline), that is in the world of the other human beings, outside the 
field/text in which football player is playing. Is this interpretation correct? If we take this interpretation for granted, the consequences are as follows:

- Sport is a human practice which exists in itself;

- Sport is a practice without communitarian, social or educational implications and values because only the individualistic dimension is important;

- In the name of freedom, sport is a hedonistic and egoistic practice whose meanings are only those given to it by the subject;

- Sport can live out of an ethics of responsibility.

This interpretation cannot be accepted. If we accept it, we will fall into the same mistakes which the interpretation of Derrida's thought has been incurring for many years. These mistakes consist of misunderstanding Derrida's relativism and Deconstructionism, as a philosophy without ethics and values (Pera, Ratzinger 2004).

The metaphor of sport used by Derrida can help us to demonstrate that this interpretation is unacceptable. From the sentence «Beyond the touchline there is nothing» we can conclude that sport is a 'text' and make a comparison with Derrida's famous and misunderstood sentence «Beyond the text there is nothing». We can try to reflect on the concept of "text".

For Derrida, "text" is something that has been made. Everything is "text", so there is nothing "outside-text" (there is no "inside-outside"). "Text" encompasses all the structures called real, economic, historic and socio-institutional; in short, all of the possible referents (Isidori 2005). The consequences of this point of view are that:

1. We are always inside sport (all is sport as all is text and we cannot stay outside this text).

2. Sport is always an interpretative experience (hermeneutical and deconstructional at the same time) in which the human being "plays" the meanings of life.

3. Sport/football is a metaphor of deconstruction.

In fact, football as a sport practice and text implies typical concepts from deconstruction such as:

- Body: that is the subject, the "interpreter", the body-mind.

- Play/game: that is interpretation and respect of rules; interaction and relation with the others inside/outside the field and beyond the "touchline" (the limits of interpretation). The others are both opponents and components of the "text" (represented by play and game themselves). Similarly, in "sport" (that is play and game) the other players are always part of a competition/contest.

- Movement: that is body's action and practice - or practical action performed to achieve something through our body. If we think it over, movement is something which is continuously temporarily differed/deferred (to another time) and continuously displaced and sent beyond (another place) by the subject/body-mind.

It is important to stress the concept of "play" ("jeu", in French, a word which has a sound very similar to "je", "I" in English) . For Derrida, "play" is not "freeplay"; it does not mean "creativity" (as in Nietzsche). Play is always play of Absence and Presence. To understand the word "cat", for example, in terms of "presence" or "self-sufficiency", what has to be overlooked is the structurally 
necessary and signifying absence of the words "bat", "fat", "sat", etc. Without such absence, there could be no Presence (Derrida 1978).

There is always some "play" or "movement" within the opposition of presence and absence. The opposition depends on this play/movement which is at the same time cause and condition of their possibility of Being. Therefore, Being must be conceived as presence or absence, as Derrida remarks, on the basis of the possibility of play and not the other way around. This is, in short, the play of deconstruction (Derrida 1974).

For Derrida, Plato and his followers were the epitome of all that was wrong with football. Plato wanted to find the perfect game, the game of games, the one true and only real way to play the game, a God's eye-view of the game. His philosophical goal was to distinguish the necessary from the contingent, the universal from the particular, and the conceptual from the concrete. Plato believed that there was one Game of games and one way to play that Game. One can say that Plato killed the game and creative essence and reduced its possibility to be performed (by mind and body). Derrida wanted to change all that.

For Derrida, Plato divided the world up into categories and he made it in order to understand and to control the world. Western thinkers have privileged objective over subjective, reason over emotion, and mind over body, and physical instinct. Much of the thinking and practice in football has been influenced by this Platonic strategy.

Being a believer in an open and fluid game, Derrida did not want to find an ultimate foundation and guarantee of knowledge, truth and the rest, but to keep the game going so that different ideas of knowledge, truth and the rest might be tried and tested.

Footballers, like philosophers, need to have passion as well as intellect; they need to be a part of the game, not apart from it. Sport as play, movement and body is a synthesis of the concept of Freedom. For Derrida, deconstructing means playing and vice-versa; and playing means understanding that life is based on the oppositional logic of difference/difference. Therefore, sport is both a metaphor of life and knowledge. From this point of view, Deconstruction is the différance that produces the différence between "this" and "that" due to the fact that without spatial and temporal separation, there could be no difference (Derrida 1982).

Since everything always exists only in relation to its spatial and temporal separation from other things, one can say that nothing exists outside of Difference (there is no outside-différance). That means that nothing is independent of its exteriority and of a field of spatiotemporal differences, intervals, and alterities. There is no "inside" without an "outside". Everything is "inside" the field or the play of the spatial and temporal relations which are "outside" of it (Stocker 2006). It is interesting to recall that when Derrida was awarded an honorary degree from Cambridge University in 1992, his critics said, ironically:

$« \mathrm{M}$. Derrida describes himself as a footballer, and his performances do indeed bear some marks of [... that discipline, [... ] but M. Derrida's work does not meet accepted standards of clarity and rigour; ... he seems to us to have come close to making a career out of what we regard as translating into the sporting sphere tricks and gimmicks similar to those of the Dadaists» (Smith 1992).

Some years later, it was said, summing up Derrida's philosophy inspired by sport:

«Derrida might well be a kind of philosophical Maradona of the footballing consciousness, a crazy combination of incomparable technical skills, unpredictable temperament and exquisite eye for the main chance who dazzles and deconstructs with his audacious fakes and feints, mazy dribbling and his deadly finish» (Hutchinson 2005, p. 56). 


\section{Derrida: between play and game}

For Derrida, human life and history should be treated as one big football field that has no inherent design or natural purpose. Western philosophy has imposed upon us a whole set of social games that privilege certain kinds of activities and ideas; it has channelled the free-play of human interaction, beliefs and practices into arbitrary structures and patterns (of values and reasoning).

In contrast to traditional thinking, Derrida's deconstructive critique goes behind those hierarchical dichotomies - objective/subjective, reason/emotion and mind/body - and he shows that they have a history and are very far from natural or obvious (Andrews 2007).

Generally speaking, football and sport put into question all kinds of issues about the way to play the game of life; in the same way, of course, issues of legality, ethics, politics and moral judgment in each person's life and daily social practices inform the performance and understanding of football.

Football is a "social text" upon which are inscribed signs from other social texts and experiences (military battle, religious ritual, class warfare, sexual encounter, cathartic release, and much else besides). Understood as a textual artifice, the game of football, although ostensibly rule-based and rule-structured activity, is never quite or only what it seems; there is always a "more" in it which is always filtered through many interpretive filters. Football can be treated as a social practice or performance that invites interpretation and obtains its meaning through its production, positioning, and role as a cultural artifact.

Any understanding of what it really means to play the game is constantly evolving and changing. In other words, the heart of football is the inconclusive and passionate game over what it means to play the game. As a cultural drama, football is able to capture the concentrated fizz that is life itself; football's text is woven in and through life's texture. In every kick, every header, every tackle, every half, every shot, every injury, every goal, every miss, we can see, know, understand and give meaning not only to the "game" in itself as a philosophical or abstract concept, but to our lives in all their complexity and possibility.

For Derrida, football, like life, is an infinitely variable process in which there is never any ultimate victory or performance, but only the repeated and unrepeatable working of the space between order and chaos, freedom and constraint, acceptance and possibility, and permanence and contingency. Being a game of infinite possibilities, football is what is and its meanings are continuously given to it by its players and fans. Like the concept of sport itself, football is only a collection of contingent understandings (or misunderstandings) of what it means to play the game. Therefore, all the philosophical or pedagogical efforts to isolate and define the essence of football (or sport) are irresistible, but irresolvable.

For all these reasons, a good football player - a good player - as a good philosopher is he who has the capacity to reveal possibilities that the rest of the football (human) community has not even seen or thought possible. Life is play and play is deconstruction: that is, a continuous meeting with a text full of meanings. For Derrida, living means learning to deconstruct the text of life in its historical, social and anthropological dimensions. In this text nothing is given a priori and there are only possibilities. From this point of view, the "text of life" is always a "competition" [a word coming from the Latin verb com-petere which means "to meet"]; it is an agón [agora is in ancient Greek the "square"], and a con-test/text [from the Latin verb cum-texere, which means "to weave with"], in which we meet, we find the others, ourselves and our culture in the texture of infinite meanings.

Sport is always a challenge for the human beings. Life is a play, but this play, which is a possibility, must be conquered by every human being. Play is a possibility we have to be free, to 
conquer our freedom in the possibility of infinite interpretations opened by the différence (the différance between presence and absence of a concept). We can try to apply the technique of différance/difference to sport saying that sport is not only a "text", but a "con-text"/"con-test":

1. It is a "con-text" (from Latin texerre), that is a texture of meanings we weave and at the same time deconstruct "together".

2. It is a "con-test" in accordance with the following two meanings:

- a con-test: (from Latin contestari), that is a call to witness, a commitment/engagement for a common safety/health, for a together answering a call; this call is the call of the other, the call of Love/Agápe, that is the communitarian Banquet of all humanity.

- a con-test: that is it is a "test" (from Latin testa, meaning "pot", "vessel" in which the ancient alchemists tested the purity of gold), according to the meaning of "to test ourselves out".

In this regard, sport is always a challenge, a cultural/anthropological space in which we challenge the world (the text itself, in which we coexist with the others and their own worlds). Derrida teaches that sport is a challenge for our traditional western ethics. He teaches that it is impossible to define exactly what sport really is, its meanings, sense and values.

\section{Deconstruction, education and new ethics}

Therefore, sport is a metaphor for education, because it is a text in which we learn to deconstruct concepts like truth, reason, justice, value and in which we learn that there are a lot of points of view on life, on values, etc. Through the exercise of deconstruction, we become more open to the difference and more critical. In Derrida deconstruction is an educational exercise. In the same way, sport is a text in which we can learn to deconstruct and it is an educational space which offers the persons who live in contemporary, complex and postmodern society a way to learn, by developing their critical thinking (Trifonas, Peters 2004).

Sport shows a new ethics to contemporary education: an ethics of the context/contest connected to the idea of Responsibility, Gift and Forgiveness (an ethics very close to the Christian one because Derrida was influenced by Levinas' thought). Sport is text and contest at the same time, that is filía, peace (we are always part of the competition/ game/ context/ contest in which we meet when we play) and not pólemos, that is war.

For this reason, Derrida's ethics and its idea of sport offers a new way:

1. To conceive not only sport education but also education (teaching and learning) in its entirety;

2. To teach and to learn to play (that is to play the game in an appropriate way, that is the human one);

3. To teach that (as educators and teachers) we are always within the Text and we have, as human beings, common roots that "Sport" (written in capital letters) shows.

In short, sport is a metaphor for education in Derrida and the good educator is:

1. He or she, like the good football player and the good philosopher, who is able to reveal possibilities that the rest of the human community have not even seen or thought possible;

2. He or she who does not impose values but shows the way to understand them because he knows that there are not incontrovertible values, like in sport, of which it is impossible to give a definite sense; 
3. He or she who teaches to subvert hierarchies and to put together all the dichotomies of thinking using the play of the différance and starting from the point of view that we are all team-mates who play together inside the same text and we are playing the same competition and match not against but with/towards life;

4. He or she who teaches to answer together responsibly and commitment (like the root of the word "contest" demonstrates) the questions and calls coming from Being.

Deconstruction is a technique that if applied to sport can offer human beings a new educational ethics. This study on Derrida, education and sport is only a starting point. We wish that in the future philosophers and educationists could take a deeper look into Derrida's thought, carrying out studies and research that, applying his thought, can help us to better understand sport, physical activity and their values and ethics.

\section{REFERENCES}

Andrews, D. L. (2007). Posting up. French structuralism and the critical analysis of contemporary sport culture. In J. Coakley \& E. Dunning (Eds), Handbook of sport studies (106-137). Thousand Oaks, CA: Sage.

Bennington, G. (1999). Jacques Derrida. Chicago: The University of Chicago Press.

Derrida, J. (1974). Of Grammatology. Baltimore: Johns Hopkins University Press.

Derrida, J. (1978). Structure, Sign and Play in the Discourse of Human Sciences. In Writing and Différance. Chicago: University of Chicago Press.

Derrida, J. (1982). Différance. In Margins of Philosophy. Chicago: The University of Chicago Press.

Hutchinson, A. C. (2005). If Derrida had played football. German Law Journal, 6 (1), pp. 53-63.

Isidori, E. (2005). Il modello decostruzionista nella ricerca pedagogica. Roma: Aracne.

Pera, M., Ratzinger, J. (2004). Without roots. The West, Relativism, Christianity. Islam. New York: Basic Books.

Smith, B. (1992). Letter. The Times, London (9 May).

Stocker B. (2006). Derrida: on deconstruction. New York: Routledge.

Trifonas, P. P., Peters, M. A. (Eds) (2004). Derrida, Deconstruction and education. Malden, MA: Blackwell Publishing. 